Share Your Innovations through JACS Directory

\title{
Trace Metals Charaterisation of Environmental Media (Soils, Water and Tree Barks) Around Cement Manufacturing Area, Nigeria
}

\author{
A.O. Majolagbe*, K.A. Yusuf, S.E. Agunbiade, V.T. Oguntan \\ Department of Chemistry, Analytical/Environmental Unit, Lagos State University, Ojo, Lagos, Nigeria.
}

\section{ARTICLE DETAILS}

Article history:

Received 13 April 2018

Accepted 17 May 2018

Available online 21 May 2018

\section{Keywords:}

Dangote

WAPCO

Environmental Media

Ibese

Sagamu

\begin{abstract}
A B S T R A C T
The industrial activities remain a major source of pollution to environment. The impact assessment of Cement productions on the environmental media: soils, groundwater and tree barks was thus investigated. Forty (40) composite soils, ten (10) groundwater and six (6) tree barks samples were collected around Dangote Cement, Ibese, and West African Portland Cement Company (WAPCO), Sagamu, Nigeria, and were analysed of trace metals following standard procedure. The concentration of $\mathrm{Fe}, \mathrm{Cr}$ and $\mathrm{Pb}$ in top soils (sub soil) around Dangote ranged from 79.5 - 393 (85.2 - 830), 7.50 - 26.0 $(12.0-25.0)$ and $2.5-68.5(2.50-11.0)(\mathrm{mg} / \mathrm{kg})$ respectively, while values around WAPCO ranged from 75.0 - 232 (49.6 - 194), 16.0 -31.0 (7.50 - 28.5) and 18.5 - 78.5 (7.50 - 66.5) (mg/kg) respectively. Reduction in metal concentrations with distance from the factories was observed. The order of trace metals in tree bark samples was $\mathrm{Fe}>\mathrm{Pd}>\mathrm{Ni}>\mathrm{Cd}>\mathrm{Cr}>\mathrm{Co}$. Although, the levels of metals observed are within the normal range found in soil, measures to avoid build-up of trace metals must be in place, to ensure a sustainable environment.
\end{abstract}

\section{Introduction}

Environmental deterioration is a major issue which confronts scientific researchers, industrialists, environmental and business policy makers on daily basis. Various industrial activities ranging from manufacturing, dredging, excavating, mining and packaging are degrading environmental ecosystems including water, air, soil fauna and flora [1]. The geometric growth of various industries, a reflection of industrial nations during the last (fifty) 50 years has, however, resulted in remarkable degradation of the environment [1]. Thus, industrial activities of which cement production is an example remain a major and important source of pollution. Therefore setting up an industry is usually guided by standards in order to make the environment safe and sustainable. Such standards include the implementation of Environmental Impact Assessment (EIA). EIA is an interdisciplinary and multi-step procedure to identify the possible environmental effects of a proposed activity, and how those impacts can be mitigated $[2,3]$.

Cement industry is one of the seventeen (17) most polluting industries listed by the central pollution control board [4-6]. It is the major source of particulate matter, $\mathrm{SO}_{\mathrm{x}}$ (Sulphur oxides), $\mathrm{NO}_{\mathrm{X}}$ (nitrogen oxides), and $\mathrm{CO}_{2}$ emissions. Cement dust contains heavy metals like chromium, nickel, cobalt, lead and mercury, which are harmful to the biotic environment with impact for vegetation, human health, animal health and ecosystem [7].

Cement is a fine, grey or white powder which is largely made up of Cement Kiln Dust (CKD), a by-product of the final cement product. Beside gaseous and particulate pollutants, Cement production also increase the levels of toxic heavy metals (like cobalt, lead, chromium, nickel, mercury) in the environment, particularly around the cement factories [8],thereby posing potential hazard for all living organisms. Increased concentrations of the above pollutants cause progressive reduction in the photosynthetic ability of leaves, and consequently, a reduction in growth and productivity of plants. Among the heavy metals, $\mathrm{Hg}, \mathrm{Pb}, \mathrm{Ni}$ and $\mathrm{Cr}$ are most dangerous heavy metals released by cement factories [9], leading to various dysfunctional biochemical changes. Cement production factories can thus pollute the air, soil, water, as well as plant.
Air pollution has a great impact on human health, climate change, agriculture and natural ecosystem [10]. Exposure to cement dust for a short period may not cause serious problem, however prolonged exposure can cause a serious and irreversible damage to plants and animals. Cement dust of sufficient quantities have been reported to dissolve leaf tissues [11]. Other reported effects of cement dust on plants include reduced growth, reduced chlorophyll, clogged stomata in leaves, cell metabolism disruption, interrupt absorption of light and diffusion of gases, lowering starch formation, reducing fruit setting, induced premature leaf fall and stunted growth thus causing suppression in plants while, it leads in animals to various respiratory and hematological disease, cancers, eye defects and genetic problems [12].

Soils around cement factories contain heavy metals such as $\mathrm{Mn}, \mathrm{Ni}, \mathrm{Fe}$, $\mathrm{Cr}, \mathrm{Zn}, \mathrm{Cu}, \mathrm{Co}, \mathrm{Pb}$ and $\mathrm{Cd}$. Increase in heavy metals content in the soil, adversely affects the soil microbial population which may have direct negative effect on the soil fertility. Environmental pressure resulting from the contaminations may reduce the biodiversity of micro-organisms and disturbs the ecological balance. Plant growth parameters, and yield components of crops are considerably influenced by excessive metals accumulation in soil.

Trace metals are found in the soil, water, biota and sediment compartments of the environment, but they potentially induce hazardous environmental effects on man when they enter the food chain [13]. Trace metals studies have been an area of active investigation over the years [14, 15]. They are important in many fields of human endeavors such as Human and Animal Nutrition, Human Health and Disease [16], Geochemistry and Environmental Pollution [17]. All trace elements are toxic to living organisms at excessive concentrations but some are essential for normal healthy growth and reproduction in both plants and animals at allowable concentrations [18].

Water around cement factory is known to contain heavy metals which exist in colloidal form, particulate and dissolved phases. High concentration of heavy metals in water bodies has an adverse effect on aquatic living organisms. Thus, the water, soil and air in the vicinities of cement productions are qualitatively affected.

This study therefore, investigated the concentration levels of potentially toxic metals in soil, groundwater, and tree barks in the vicinities of Dangote Cement Factory, (Ibese), and West African Portland Cement Company (WAPCO), Sagamu. 


\section{Experimental Methods}

\subsection{Study Area}

The study area is comprised of the Dangote cement factory at Ibese and West African Portland Cement Company (WAPCO), Sagamu, Ogun state, Nigeria.

\subsubsection{Dangote Cement Factory (Ibese Plant)}

Dangote Cement Factory is located at Ibese, Yewa North Local Government Area via Ilaro, Ogun state. The factory is situated in Latitude $7^{\circ} 0$ '25.97"N and Longitude $3^{\circ} 2^{\prime} 56.98$ 'E. The major deposit in this area is limestone. The Ibese cement factory (Dangote cement) was established in 2012.

\subsubsection{West African Portland cement Factory (WAPCO - Sagamu Plant)}

Sagamu is the host community of West African Portland Cement Factory (WAPCO). Sagamu is located in Ogun state, South Western Nigeria. Its geographical coordinates are $6^{\circ} 50^{\prime} \mathrm{N}$ and $3^{\circ} 39^{\prime} \mathrm{E}$. Lafarge cement (Sagamu Plant) has the geographical coordinate of Latitude $6.833^{\circ} \mathrm{N}$ and Longitude $3.650^{\circ} \mathrm{E}$. The major deposits in this area is the limestone. The Sagamu cement factory was established in 1978 and has two kilns, operating on wet process.

\subsection{Sampling}

A total number of forty (40) soil samples at $(0-15 \mathrm{~cm})$ and $(15-30 \mathrm{~cm})$ for top and sub soils respectively, six (6) tree bark samples, and twenty groundwater samples were collected. The sampling sites were carefully chosen after a pre-sampling site survey. Composite soil samples were collected at different selected sampling points in order to provide a good coverage of the study site with the use of a soil auger and they were transferred into clean acid-washed polyethylene bags. Tree bark samples were collected at a height of $3 \mathrm{~m}$ above the ground level using a clean acid washed stainless steel knife. The knife was further washed after each sampling to avoid cross contamination. The bark samples were placed in clean polyethylene bags.

The water samples were collected into $0.5 \mathrm{~L}$ plastic container. The plastic containers were washed with a detergent, rinsed with warm water and then with distilled water before soaking in $10 \% \mathrm{HNO}_{3}$ overnight [19]. During the sampling, the $0.5 \mathrm{~L}$ water samples were spiked with $1 \mathrm{ml}$ of concentrated $\mathrm{HNO}_{3}$ (Analar) in order to preserve the samples. All samples were transported to the laboratory, while the soil and tree bark samples were air dried at room temperature, and the water samples were stored in the refrigerator at $4^{\circ} \mathrm{C}$ until analysis.

\subsection{Experimental Procedure}

The $\mathrm{pH}$ of soil samples, and heavy metal load in soil, water and tree bark sample were investigated by employing standard procedure.

\subsubsection{Sample Preparation}

Soil Samples: The soil samples were air-dried, pulverized, and sieved through a $2 \mathrm{~mm}$ mesh sieve size. The sieved samples were then stored at room temperature prior to analysis.

Tree Bark Samples: The bark samples were air-dried, and pulverized. The samples were then stored at room temperature prior to analysis.

\subsection{2 pH Measurement of Soil and Water Samples}

About $20.0 \mathrm{~g}$ of each of the soil samples was weighed into a clean 250 $\mathrm{mL}$ beaker, $20 \mathrm{~mL}$ distilled water was added, and the mixture was allowed to stand for 30 minutes with occasional stirring using a glass rod. The $\mathrm{pH}$ was then measured using a pH meter mode HI96304 already calibrated with buffers of $\mathrm{pH} 4,7$, and 9. The result was recorded as soil $\mathrm{pH}$ measured in water.

The $\mathrm{pH}$ and temperature of ground water samples were measured at sampling point, the $\mathrm{pH}$ measurement were carried out with $\mathrm{pH}$ meter (HI96304) and temperature was given by a thermometer.

\subsubsection{Heavy Metal Content of the Soil and Water Samples (Wet Digestion)}

About $2.0 \mathrm{~g}$ of each of the soil samples were weighed into a $250 \mathrm{~mL}$ beaker and moistened with few drops of distilled water to prevent loss by spattering during digestion. The sample was digested with $10 \mathrm{~mL}$ of concentrated $\mathrm{HNO}_{3}$ on a hot plate in a fume cupboard until the volume was about $3 \mathrm{~mL}$. The residues obtained were further digested with a mixture of concentrated acids containing $5 \mathrm{~mL}$ each of $\mathrm{HCl}, \mathrm{HNO}_{3}$ and $\mathrm{HClO}_{4}$ at room temperature for 10 minutes until the solution was brought to a final volume of about $5 \mathrm{~mL}$ on a hot plate in a fume cupboard. The digest was https://doi.org/10.30799/jespr.123.18040203 allowed to cool and filtered into a $100 \mathrm{~mL}$ volumetric flask using Whatman No.1 filter paper. It was then made up to mark with the distilled water. Blank sample was made with the same procedure.

\subsubsection{Heavy Metal Content of the Tree Bark Samples (Wet digestion)}

About $2.0 \mathrm{~g}$ of pulverized tree bark sample was weighed into $250 \mathrm{~mL}$ beaker, a mixture of $20 \mathrm{~mL} \mathrm{HNO}_{3}$ and $8 \mathrm{~mL} \mathrm{HClO}_{4}$ was used to digest the samples on a hotplate in a fume cupboard to a final volume of $5 \mathrm{~mL}$. The digest was cooled, drops of distilled water were added and the solution was filtered into a volumetric flask using Whatman No. 1 filter paper. The flask was then made up to $100 \mathrm{~mL}$ mark with distilled water. Blank sample was made with the same procedure.

\subsection{Statistical Analysis}

The data obtained from chemical analyses were subjected to statistical treatment using mean, standard deviation and correlation coefficient matrices in order to establish elements association. Clustered bar chart was given to describe element concentration in soil, tree bark and water samples.

\section{Results and Discussion}

3.1 Soil Analyses

3.1.1 $\mathrm{pH}$ of soil samples

The $\mathrm{pH}$ of the soil samples around Dangote cement factory, Ibese, ranged from 6.2 to 8.3 with mean value of 7.6 for top soils and ranged from 5.4 to 7.8 with a mean value of 6.90 for sub soils which are indicated in Table 1. In soil samples collected around WAPCO, Sagamu, the pH ranged from 7.9 to 8.5 with mean value of 8.1 for top soils and ranged from 5.8 to 7.2 with a mean value of 6.5 for sub soils, shown in Table 2 . The $\mathrm{pH}$ generally plays an important role in metal bioavailability, toxicity and leaching capacity in the environment [12]. Trace metals are mostly more soluble and leach out in acidic $\mathrm{pH}[14]$.

\subsubsection{Concentration of Metals in Soil Samples}

The results of the concentration ( $\mathrm{mg} / \mathrm{kg}$ ) of the trace metals level in top soil and sub soil samples around Dangote Ibese and WAPCO, Sagamu cement factories, are given in Tables 1 and 2 respectively. The result showed that the concentrations of metals analysed in the soil samples are within the world range given by WHO 1996. The concentration levels of metals is in the order of $\mathrm{Fe}>\mathrm{Cr}>\mathrm{pd}>\mathrm{Ni}>\mathrm{Cd}>\mathrm{Co}$. The concentration levels of $\mathrm{Fe}, \mathrm{Cr}$ and $\mathrm{Pb}$ are higher in the soil samples in the vicinities of the cement factory than in the control sample. From Table 1, Fe has the highest mean concentration of $187.00 \pm 101.00 \mathrm{mg} / \mathrm{kg}$ for top soils and $289.00 \pm$ $240.00 \mathrm{mg} / \mathrm{kg}$ for sub soils around Dangote cement factory, while in WAPCO, Sagamu, Table 2, Fe has the highest mean concentration of 136.00 $\pm 47.00 \mathrm{mg} / \mathrm{kg}$ for top soils and $110.00 \pm 55.00 \mathrm{mg} / \mathrm{kg}$ for sub soils. The Clustered bar chart of metals concentration in soil samples around Dangote cement and WAPCO cement are shown in Figs. 1 and 2 respectively. Fe is the most abundant element in the earth crust; this explains the high mean value, but still lower than the WHO limit of 21000 $\mathrm{mg} / \mathrm{kg}$. Top soil is usually the choice in a metal pollution like this, because it covers the zone in which roots of plants such as cassava maize and vegetable absorb water and minerals. The results of metal concentration in both Dangote Cement Factory, Ibese and WAPCO, Sagamu were subjected to correlation coefficient (Tables 3 and 4). Fe was found to have a positive correlation $(\mathrm{p}>0.05)$ with $\mathrm{Cr}$, while a negative correlation was found between $\mathrm{Fe}, \mathrm{Pb}$ and $\mathrm{Cr}$. The positive or strong correlation indicates that these metals are not from the same source. This can be as a result of the contribution of other sources like dump site, automobile, agricultural waste water, where fertilizers are used.

\subsection{Tree Bark Analyses}

The results of the concentration of metals in tree bark samples around Dangote cement and WAPCO cement factories are shown in Tables 5 and 6 respectively, while the Clustered bar charts of metals concentration in tree bark samples around Dangote and WAPCO cement factories, are shown in Figs. 3 and 4 respectively. The results obtained show that Fe has the highest concentration in the tree bark samples at both Dangote cement factory and WAPCO cement factory. The surface structure of the tree bark sample has influence on the rate of accumulation of metals. A tree bark with a rough surface absorbs pollutants than a smooth surface. The bark of tree has been reported to be a good bio-indicator, and this study has proven so with varying degree of concentration of heavy metals as shown in Tables 5 and 6. The mango tree (Mangifera indica) has the highest value in concentration possibly due to the roughness of the surface of the stem which tells its ability to absorb the heavy metals. 
Table 1 Levels of trace metals in topsoil and subsoil samples $(\mathrm{mg} / \mathrm{kg}$ ) around Dangote cement factory, Ibese

\begin{tabular}{|c|c|c|c|c|c|c|c|c|c|c|c|c|c|c|}
\hline \multicolumn{2}{|c|}{ Metals } & Soil 1 & Soil 2 & Soil 3 & Soil 4 & Soil 5 & Soil 6 & Soil 7 & Soil 8 & Soil 9 & Soil 10 & Mean & SD & WHO [20] \\
\hline \multirow[t]{2}{*}{$\mathrm{Fe}$} & ITS & 326 & 171 & 142 & 93.6 & 142 & 176 & 119 & 226 & 393 & 79.5 & 187 & 101 & 21000 \\
\hline & ISS & 259 & 830 & 609 & 194 & 172 & 98.3 & 85 & 168 & 350 & 136 & 289 & 240 & \\
\hline \multirow[t]{2}{*}{ Co } & ITS & ND & ND & ND & ND & ND & ND & ND & ND & ND & ND & ND & ND & 65 \\
\hline & ISS & ND & ND & ND & ND & ND & ND & ND & ND & ND & ND & ND & ND & \\
\hline \multirow[t]{2}{*}{$\mathrm{Cr}$} & ITS & 11.00 & 21.00 & 19.50 & 13.00 & 15.50 & 10.50 & 13.00 & 17.00 & 26.00 & 7.50 & 15.40 & 5.60 & 400 \\
\hline & ISS & 25.00 & 21.50 & 23.00 & 20.50 & 16.50 & 13.00 & 12.00 & 12.00 & 18.00 & 15.00 & 17.70 & 4.70 & \\
\hline \multirow[t]{2}{*}{$\mathrm{Cd}$} & ITS & 0.10 & 0.10 & 0.10 & 0.10 & 0.10 & 0.10 & 0.10 & 0.10 & 0.10 & 0.10 & 0.10 & 1.50 & 3 \\
\hline & ISS & 0.10 & 0.10 & 0.10 & 0.10 & 0.10 & 0.10 & 0.10 & 0.10 & 0.10 & 0.10 & 0.10 & 1.50 & \\
\hline \multirow[t]{2}{*}{$\mathrm{Pb}$} & ITS & 2.50 & 2.50 & 2.50 & 6.85 & 2.50 & 2.50 & 2.50 & 2.50 & 2.50 & 2.50 & 2.94 & 1.40 & 300 \\
\hline & ISS & 2.50 & 2.50 & 2.50 & 1.10 & 9.50 & 2.50 & 2.50 & 2.50 & 2.50 & 2.50 & 3.06 & 2.30 & \\
\hline \multirow[t]{2}{*}{$\mathrm{Ni}$} & ITS & 0.15 & 0.15 & 0.15 & 0.15 & 0.15 & 0.15 & 0.15 & 0.15 & 0.15 & 0.15 & 0.15 & 2.90 & 50 \\
\hline & ISS & 0.15 & 0.15 & 0.15 & 0.15 & 0.15 & 0.15 & 0.15 & 0.15 & 0.15 & 0.15 & 0.15 & 2.90 & \\
\hline \multirow[t]{2}{*}{$\mathrm{pH}$} & ITS & 8.30 & 7.40 & 8.10 & 7.60 & 7.30 & 7.40 & 6.20 & 8.00 & 8.00 & 7.50 & 7.58 & 0.60 & - \\
\hline & ISS & 7.70 & 6.90 & 6.80 & 7.20 & 7.10 & 5.40 & 5.70 & 7.50 & 7.50 & 7.80 & 6.96 & 0.81 & \\
\hline
\end{tabular}

NB: ITS: Ibese top soil, ISS: Ibese sub soil

Table 2 Levels of trace metals in topsoil and subsoil samples $(\mathrm{mg} / \mathrm{kg}$ ) around WAPCO cement factory, Sagamu

\begin{tabular}{|c|c|c|c|c|c|c|c|c|c|c|c|c|c|c|}
\hline \multicolumn{2}{|c|}{ Metals } & \multirow{2}{*}{$\begin{array}{l}\text { Soil } 1 \\
185\end{array}$} & \multirow{2}{*}{$\begin{array}{l}\text { Soil } 2 \\
102\end{array}$} & \multirow{2}{*}{\begin{tabular}{|l|} 
Soil 3 \\
124
\end{tabular}} & \multirow{2}{*}{$\begin{array}{l}\text { Soil } 4 \\
133\end{array}$} & \multirow{2}{*}{$\begin{array}{l}\text { Soil 5 } \\
118\end{array}$} & \multirow{2}{*}{$\begin{array}{l}\text { Soil } 6 \\
86.9\end{array}$} & \multirow{2}{*}{$\begin{array}{l}\text { Soil } 7 \\
232\end{array}$} & \multirow{2}{*}{$\begin{array}{l}\text { Soil } 8 \\
144\end{array}$} & \multirow{2}{*}{$\begin{array}{l}\text { Soil 9 } \\
162\end{array}$} & \multirow{2}{*}{$\begin{array}{l}\text { Soil } 10 \\
75\end{array}$} & \multirow{2}{*}{$\begin{array}{l}\text { Mean } \\
136\end{array}$} & \multirow{2}{*}{$\begin{array}{l}\text { SD } \\
47\end{array}$} & \multirow{2}{*}{$\begin{array}{l}\text { WHO [20] } \\
21000\end{array}$} \\
\hline Fe & STS & & & & & & & & & & & & & \\
\hline & SSS & 159 & 126 & 184 & 122 & 65.9 & 49.8 & 70.8 & 194 & 83 & 49.6 & 110 & 55 & \\
\hline \multirow[t]{2}{*}{ Co } & STS & ND & ND & ND & ND & ND & ND & ND & ND & ND & ND & ND & ND & 65 \\
\hline & SSS & ND & ND & ND & ND & ND & ND & ND & ND & ND & ND & ND & ND & \\
\hline \multirow[t]{2}{*}{$\mathrm{Cr}$} & STS & 25.50 & 19.50 & 22.00 & 26.50 & 24.00 & 19.00 & 31.00 & 23.50 & 22.50 & 16.00 & 22.90 & 4.30 & 400 \\
\hline & SSS & 20.00 & 25.00 & 17.00 & 28.50 & 7.50 & 15.00 & 14.50 & 21.00 & 16.50 & 25.50 & 19.05 & 6.30 & \\
\hline \multirow[t]{2}{*}{$\mathrm{Cd}$} & STS & 0.10 & 0.10 & 0.10 & 0.10 & 0.10 & 0.10 & 0.10 & 0.10 & 0.10 & 0.10 & 0.10 & 1.50 & 3 \\
\hline & SSS & 0.10 & 0.10 & 0.10 & 0.10 & 0.10 & 0.10 & 0.10 & 0.10 & 0.10 & 0.10 & 0.10 & 1.50 & \\
\hline \multirow[t]{2}{*}{$\mathrm{Pb}$} & STS & 27.00 & 18.50 & 37.50 & 52.50 & 67.50 & 78.50 & 52.00 & 38.00 & 42.00 & 17.50 & 43.10 & 20.00 & 300 \\
\hline & SSS & 17.50 & 23.00 & 12.50 & 66.50 & 22.50 & 25.50 & 7.50 & 18.00 & 13.50 & 22.50 & 22.90 & 16.00 & \\
\hline \multirow[t]{2}{*}{$\mathrm{Ni}$} & STS & 0.15 & 0.15 & 0.15 & 0.15 & 0.15 & 0.15 & 0.15 & 0.15 & 0.15 & 0.15 & 0.15 & 2.90 & 50 \\
\hline & SSS & 0.15 & 0.15 & 0.15 & 0.15 & 0.15 & 0.15 & 0.15 & 0.15 & 0.15 & 0.15 & 0.15 & 2.90 & \\
\hline \multirow[t]{2}{*}{$\mathrm{pH}$} & STS & 8.30 & 7.90 & 8.20 & 8.30 & 7.90 & 8.10 & 8.00 & 8.00 & 8.10 & 8.50 & 8.13 & 0.20 & - \\
\hline & SSS & 5.80 & 6.10 & 6.40 & 6.30 & 6.50 & 6.10 & 7.20 & 6.70 & 6.80 & 6.60 & 6.45 & 0.40 & \\
\hline
\end{tabular}

NB: STS: Sagamu top soil, SSS: Sagamu sub soil

Table 3 Correlation coefficient of metals in soil around Dangote cement factory

\begin{tabular}{llll}
\hline & $\mathrm{Fe}$ & $\mathrm{Cr}$ & $\mathrm{Pb}$ \\
\hline $\mathrm{Fe}$ & 1.00 & & \\
$\mathrm{Cr}$ & 0.90 & 1.00 & \\
$\mathrm{~Pb}$ & -0.30 & -0.04 & 1.00 \\
\hline
\end{tabular}

Table 5 Trace metals $(\mathrm{mg} / \mathrm{kg})$ in tree bark samples around Dangote Ibese

\begin{tabular}{lllllll}
\hline Sample Code & $\mathrm{Fe}$ & $\mathrm{Co}$ & $\mathrm{Cr}$ & $\mathrm{Cd}$ & $\mathrm{Pb}$ & $\mathrm{Ni}$ \\
\hline ITB1 & 55.00 & ND & ND & 0.10 & 2.50 & 0.15 \\
ITB2 & 25.00 & ND & ND & 0.10 & 2.50 & 0.15 \\
ITB3 & 125.00 & ND & ND & 0.10 & 2.50 & 0.15 \\
Mean & 68.50 & ND & ND & 0.10 & 2.50 & 0.15 \\
SD & 51.00 & ND & ND & 1.70 & 0.00 & 0.00 \\
WHO & 1000 & 1 & 50 & 0.5 & 10 & 2 \\
\hline
\end{tabular}

NB: ITB: Ibese tree bark

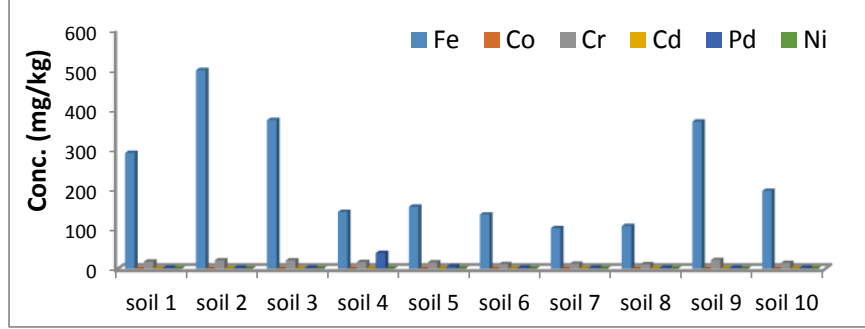

Fig. 1 Clustered bar chart showing metals concentration in soil samples around Dangote cement

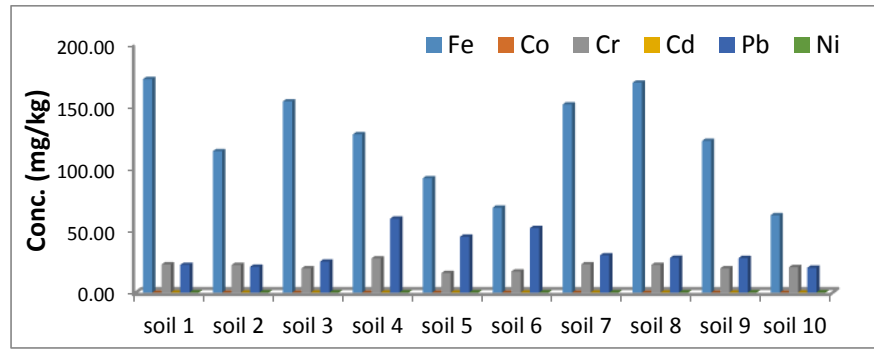

Fig. 2 Clustered bar chart showing metals concentration in soil samples around WAPCO, Sagamu

https://doi.org/10.30799/jespr.123.18040203

Cite this Article as: : A.O. Majolagbe, K.A. Yusuf, S.E. Agunbiade, V.T. Oguntan, Trace Metals charaterisation of environmental media (soils, water and tree barks) around cement manufacturing area, Nigeria, J. Env. Sci. Pollut. Res. 4(2) (2018) 271-274.
Table 4 Correlation coefficient of metals in soil around WAPCO cement factory

\begin{tabular}{llll}
\hline & $\mathrm{Fe}$ & $\mathrm{Cr}$ & $\mathrm{Pb}$ \\
\hline $\mathrm{Fe}$ & 1.00 & & \\
$\mathrm{Cr}$ & 0.49 & 1.00 & \\
$\mathrm{~Pb}$ & -0.30 & 0.03 & 1.00 \\
\hline
\end{tabular}

Table 6 Trace metals (mg/kg) in tree bark samples around WAPCO, Sagamu

\begin{tabular}{lllllll}
\hline Sample Code & Fe & Co & Cr & Cd & Pb & Ni \\
\hline STB1 & 15.50 & ND & ND & 0.10 & 2.50 & 0.15 \\
STB2 & 316.00 & ND & ND & 0.10 & 2.50 & 0.15 \\
STB3 & 205.00 & ND & 4.50 & 0.10 & 2.50 & 0.15 \\
Mean & 179.00 & ND & 1.50 & 0.10 & 2.50 & 0.15 \\
SD & 150.00 & ND & 2.60 & 1.70 & 0.00 & 0.00 \\
WHO & 1000 & 1 & 50 & 0.5 & 10 & 2 \\
\hline
\end{tabular}

NB: STB: Sagamu tree bark

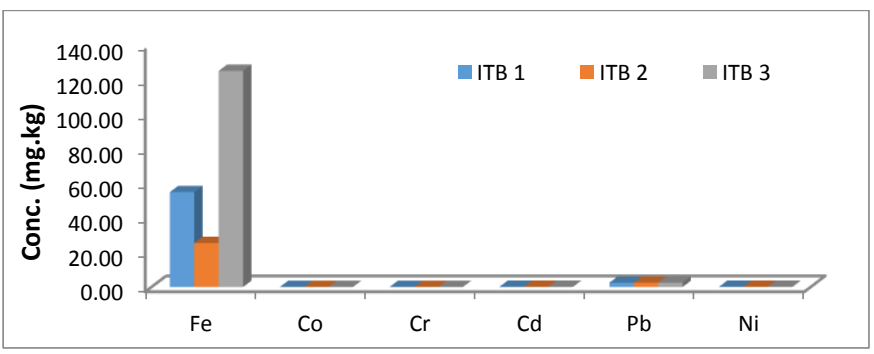

Fig. 3 Clustered bar chart showing metal concentration in tree bark samples around Dangote cement factory, Ibese

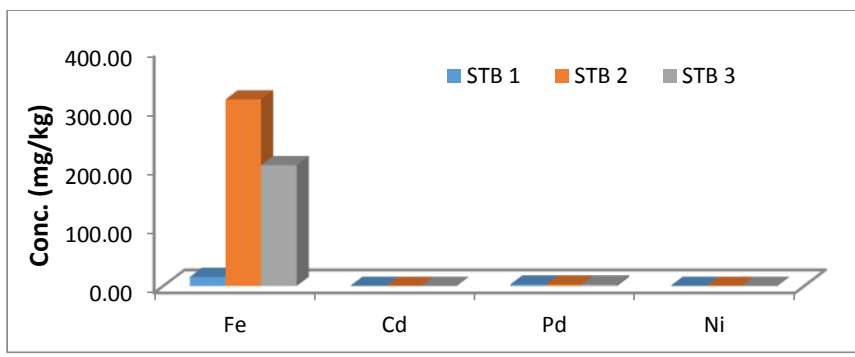

Fig. 4 Clustered bar chart showing metal concentration in tree bark samples around WAPCO, Sagamu 


\subsection{Water Analyses}

The result of the concentration of the metals in the area's groundwater samples is given in Table 7 and bar chart showing metal concentration in tree bark samples around WAPCO, Sagamu is presented in Fig. 5. The level of Fe in the water samples was found to be higher than all the other metals with mean concentration of $0.127 \pm 0.061 \mathrm{mg} / \mathrm{L}$. The concentration of the metals follow the decreasing order, $\mathrm{Fe}>\mathrm{Pb}>\mathrm{Ni}>\mathrm{Cd}$, while $\mathrm{Co}$ and $\mathrm{Cr}$ were not detected.

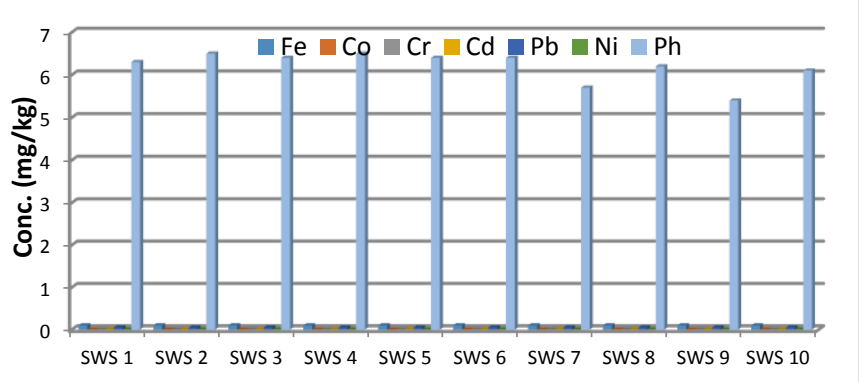

Fig. 5 Clustered bar chart showing metal concentration in tree bark samples around WAPCO, Sagamu

Table 7 Trace metals concentration $(\mathrm{mg} / \mathrm{kg})$ in groundwater samples around WAPCO, Sagamu

\begin{tabular}{llllllll}
\hline Sample & $\mathrm{Fe}$ & $\mathrm{Co}$ & $\mathrm{Cr}$ & $\mathrm{Cd}$ & $\mathrm{Pb}$ & $\mathrm{Ni}$ & $\mathrm{Ph}$ \\
\hline SWS 1 & 0.100 & ND & ND & 0.002 & 0.050 & 0.003 & 6.300 \\
SWS 2 & 0.100 & ND & ND & 0.002 & 0.050 & 0.003 & 6.500 \\
SWS 3 & 0.100 & ND & ND & 0.002 & 0.050 & 0.003 & 6.400 \\
SWS 4 & 0.100 & ND & ND & 0.002 & 0.050 & 0.003 & 6.500 \\
SWS 5 & 0.100 & ND & ND & 0.002 & 0.050 & 0.003 & 6.400 \\
SWS 6 & 0.100 & ND & ND & 0.002 & 0.050 & 0.003 & 6.400 \\
SWS 7 & 0.100 & ND & ND & 0.002 & 0.050 & 0.003 & 5.700 \\
SWS 8 & 0.100 & ND & ND & 0.002 & 0.050 & 0.003 & 6.200 \\
SWS 9 & 0.100 & ND & ND & 0.002 & 0.050 & 0.003 & 5.400 \\
SWS 10 & 0.100 & ND & ND & 0.002 & 0.050 & 0.003 & 6.100 \\
Mean & 0.127 & ND & ND & 0.002 & 0.050 & 0.003 & 6.190 \\
SD & 0.061 & ND & ND & 4.600 & 7.300 & 4.500 & 0.350 \\
\hline
\end{tabular}

NB: SWS: Sagamu water sample

\section{Conclusion}

Results of this study reveal that trace metal pollution level in cement production areas are not totally of natural geology but as a result of the activities of the cement factories on the environment, thereby indicating the impact of the factory in the area. High concentration of trace metals were obtained in the soils around the cement factory compared to soils from control area in the study area. The accumulation of these potential toxic metals must be monitored in order to prevent environmental pollution which can affect life. Therefore strict compliance on environmental laws must be followed by the cement factories to ensure safety of life and environment.

\section{References}

[1] M. Murugesan, A. Sivakumar, N. Jayanthi, K. Manonmani, Effect of cement dust pollution of physiological and biochemical activities of certain plants, Pollut. Res. 232 (2004) 375-378

[2] WBCSD, Environmental and social impact assessment (ESIA) guidelines, World Business Council for Sustainable Development, Geneva, 2005.

[3] F. Vanclay, Social impact assessment, In: International Handbook of Environmental Impact Assessment, Blackwell Science, Oxford, 1999.

[4] S. Medina, A.L. Tertre, M. Saklad, The apheis project: Air pollution and healthEuropean information system, Air. Qual. Atmos. Health. 2(2009) 185-198.

[5] M.O. Akinola, N.A. Okwok, T. Yahaya, The effects of cement dust on Albino rats (Rattus orvegicus) around West African Portland cement factory in Sagamu, Ogun State, Nigeria, Res. J. Environ. Toxicol. 2(1) (2008) 1-8.

[6] A.M. Gbadebo, O.D. Bankole, Analysis of potentially toxic metals in airborne cement dust around Sagamu, Southwestern Nigeria, Jour. Appl. Sci. 7 (2007) 35-40.

[7] A. Chidambaram, P. Sundaramoorthy, A. Murugan, K. Sankar, B.L. Ganesh, A. Chidambaram, Chromium induced cytotoxicity in blackgram (Vignamungo L.) Iran. J. Environ. Health Sci. Eng. 6 (2009) 17-22.

[8] T. Ritambhara, G. Kumar, Genetic loss through heavy metal induced chromosomal stickiness in Grass pea, Plant Genetics Laboratory, Department of Botany, University of Allahabad, Allahabad, India, 2010.

[9] J.H. Zou, M. Wang. W.S. Jiang, D.H. Liu, Effects of hexavalent chromium (VI) on root growth and cell division in root tip cells of Amaranthus viridis, L., Pak. J. Bot. 38(3) (2006) 673-681.

[10] J.O. Ogunbileje, O.M. Akinosun, Biochemical and hematological profile in Nigerian cement factory workers, Res. J. Environ. Toxicol. 5 (2011) 133-140.

[11] S. Baby, N.A. Singh, P. Srivastava, S.R. Nath, S. S. Kumar, D. Singh, K. Vivek. Impact of dust emission on plant vegetation of vicinity of cement plant, Environ. Eng. Manag. Jour. 7 (2008) 31-35.

[12] L. Chimuka, 0.0. John, Metals in environmental media: Study of platinum group metals in Thohoyandou, South Africa, Water Res. 31 (2005) 581-586.

[13] J.T. Ayodele, C.D. Oluyemi, Grass contamination by trace metals from road traffic, Jour. Environ. Chem. Ecotoxicol. 3 (2010) 60-67.

[14] O.S. Fatoki, Z. Mbolekwa, O.R. Awofolu, Levels of trace metals in water and sediment from Tyumen River and its effect on an irrigated farmland, Alice SA Water Res. 1 (2004) 87-96.

[15] A.A. Okoya, O.I. Asubiojo, A.A. Amusan, Trace element concentrations of soils of Ife-Ijesa area Southwestern Nigeria, Jour. Environ. Chem. Ecotoxicol. 3 (2011) 173-179.

[16] B.E. Davies, Trace metals in the environment: Retrospect and prospect, In: Biogeochemistry of trace metals, Lewis Publishers, Boca Raton Ann Arbor London, Tokyo, 1992.

[17] J.O. Nriagu, Chemistry of the river Niger, I: Major ions, II: Trace metals, Sci. Tot. Environ. 58 (1986) 81-92.

[18] C. Anyakora, K. Nwaeze, O. Awodele, C. Nwadike, M. Arbabi, C.H. Herbert, Concentrations of heavy metals in some pharmaceutical effluents in Lagos, Nigeria, Jour. Environ. Chem. Ecotoxicol. 3 (2011) 25-31.

[19] A.O. Majolagbe, K.A. Yusuf, A.E. Duru, Trace metals characterization in environmental media: A case study of cement production area, Ewekoro, Southwest, Nigeria, Am. J. Environ. Protect. 3 (2014) 83-89.

[20] WHO, Trace elements in human nutrition and health, World Health Organization, Geneva, 1996 